DOI

\title{
ІНОВАЦІЙНІ СПОСОБИ ЕНЕРГОПІДВЕДЕННЯ У ПРОЦЕСАХ СУШІННЯ ТЕРМОЛАБІЛЬНОЇ СИРОВИНИ
}

\author{
Яровий І.І., к.т.н., Кашкано М.А., к.т.н., Маренченко О. І., аспірант, Пилипенко Є.О., інженер. \\ Одеська національна академія харчових технологій
}

\begin{abstract}
Анотація. Обумовлено причини зростання обсягів сушіння рослинної сировини. Визначено актуальність пошуку та дослідження нових способів енергопідведення в прочесах сушіння рослинної сировини. Показано основні переваги мікрохвильового сушіння порівняно з традиційними конвенційними технологіями сушіння. Визначено основні недоліки та обмеження мікрохвильового сушіння. Показано зв'язок теми дослідження з напрямами наукової роботи кафедри процесів, обладнання та енергетичного менеджменту. Обрано робочу гіпотезу про взаємодію мікрохвильового поля з вологою в капілярно-пористих структурах. Визначено відмінності в процесі енергопідведення при мікрохвильовому та конвекційному сушінні. Визначено основні конструктивні обмеження для дизайну мікрохвильових сушильних апаратів. Описано обсяг та зміст проведених раніше досліджень. Приведено узагальнений аналіз результатів дослідження мікрохвильового сушіння для різних видів рослинної сировини. Обтрунтовано вибір апаратурної схеми установки для сушіння рослинної сировини в потоці. Визначено основні конструктивні рішення та обмеження, шзо визначають конструкцію мікрохвильової сушильної установки для рослинних матеріалів. Описано конструкцію та принции дї дослідної стрічкової мікрохвильової сушильної установки створеної для проведення дослідження. Описано порядок проведення експериментального мікрохвильового сушіння насіння соняшника. Визначено основні залежності прочесу мікрохвильового сушіння соняшника. Досліджено залежність між швидкістю вологовидалення та потужністю електромагнітного підведення енергії а також тривалістю сушіння. Визначено основні переваги комбінованого сушіння з використанням мікрохвильового та інфрачервоного випромінювання. Описано конструкцію та принции дії установки для дослідження процесу вологовидалення при інфрачервоному сушіння. Визначено залежності кінетики процесу від величини енергопідведення та тривалості енергетичного впливу. Приведено аналіз отриманих результатів. Надано обтрунтування для наступного етапу дослідження.
\end{abstract}

Ключові слова: електромагнітні джерела енергії, мікрохвильові апарати, мікрохвильове сушіння, інфрачервоне сушіння, комбіноване сушіння, сушіння рослинної сировини, нові способи сушіння.

\section{INNOVATIVE ENERGY INSTRUCTIONS FOR DRYING THERMALABLE RAW MATERIALS}

Yarovyi I.I., Ph.D., Kashkano M.A., Ph.D., Marenchenko O.I., postgraduate student, Pilipenko E.O., engineer.

Odesa National Academy of Food Technologies

\begin{abstract}
Causes of growth of volumes of drying of plant material are caused. The actuality of search and research of new methods of power transfer in processes of drying of plant material is determined. The main advantages of microwave drying are shown in comparison with conventional drying technologies. The main drawbacks and limitations of microwave drying are determined. The relation between the topic of the research and the directions of the scientific work of the department is shown. The working hypothesis on the interaction of the microwave field with moisture in the capillary - porous structures is chosen. The differences in the process of energy transfer during microwave and convection drying are determined. The basic design constraints for the design of microwave drying machines are determined. The scope and content of previous studies are described. A generalized analysis of the results of microwave drying for different types of plant material is given. The choice of equipment scheme for plants for drying of plant raw materials in the flow is grounded. The basic design decisions and constraints determining the design of a microwave drying plant for plant materials are determined. The design and principle of the experimental microwave drying device created for the research is described. The procedure for conducting experimental microwave drying of sunflower seeds is described. The basic dependences of the process of microwave drying of sunflower are determined. The dependence between the velocity of moisture reduction and the power of the electromagnetic energy supply is investigated. The dependence between the rate of moisture reduction and the power of the electromagnetic energy supply as well as the drying time is investigated. The main advantages of combined drying using the microwave and infrared radiation are determined. The design and principle of operation of the installation for the study of the process of moisture reduction during infrared drying are described. The
\end{abstract}


basic dependencies of the process are determined. The analysis of the obtained results is given. Substantiation for the next stage of the research is given.

Keywords: electromagnetic energy sources, microwave ovens, microwave drying, infrared drying, combined drying, drying of vegetable raw materials, new drying methods.

Вступ. У сучасному високотехнологічному виробництві продуктів харчування, рослинна сировина відіграє провідну і вирішальну роль. Посилюються тенденції щодо часткової заміни окремих видів сировини тваринного походження на рослинну сировину. Все більшого значення у виробництві продуктів харчування набувають попередньо скомпоновані з різних складових порошки та суміші, створені, як правило, на базі попередньо оброблених компонентів рослинної сировини.

Однією з традиційних технологій обробки, консервації та знезараження рослинної сировини є сушіння. Зниження вологості матеріалу для збереження його якості при тривалому зберіганні є однією з найстаріших технологій обробки.

Актуальність. Основним способом енергопідведення в традиційних технологіях сушіння є конвективна теплопередача. Використання для передачі тепла проміжного теплоносія, обов'язково супроводжується непродуктивними втратами: при генерації первинного тепла, його передачі теплоносію, транспортуванні теплоносія до об'єкту сушіння, нагріванні матеріалу об'єкта під впливом теплоносія, і тільки в кінці цього ланцюга конверсій енергії знаходиться цільовий вплив - саме нагрівання вологи, що міститься в матеріалі. Конвективні технології сушіння розвиваються вже десятки років, можливості подальшого покращення їх енергоефективності обмежені фізикою процесів теплопередачі.

Слід припустити, що серед конкуруючих способів сушіння, не конвективних, розвиток мають отримати ті, які мають менший ланцюг конверсій і відповідно більший потенціал енергоефективності.

Достатньо давно відомим, проте малопоширеним способом зневоднення матеріалів $є$ сушіння в електромагнітному полі надвисокої частоти $[1,2,3]$. Так як найчастіше для створення надвисокочастотного поля використовують магнетрони 3 частотою генерації 2400 МГц, апарати на базі таких генераторів називають мікрохвильовими сушарками.

Ще більш перспективними виглядають технології комбінованого сушіння [4,5,6,7], наприклад посилення переваг мікрохвильового сушіння за рахунок поєднання з інфрачервоним енергопідведенням або з вакуумуванням. При такому способі сушіння переваги обох видів енергопідведення не будуть простою сумою переваг, при злагодженому дозуванні кожного з потоків має спрацювати синергетична складова, внаслідок чого комбіноване сушіння може показати надвисоку продуктивність вологовидалення та недосяжну для конвективних технологій якість висушеного продукту.

Мета та зміст досліджень. Комплекс проблем, що супроводжують використання мікрохвильових технологій у процесах переробки і зберігання сировини та продуктів виробництва $є$ однією з точок фокусування наукових інтересів дослідницьких програм кафедри. Значна частина досліджень послідовників наукової школи професора О.Г. Бурдо тим чи іншим чином пов'язана з використанням мікрохвильових технологій енергопідведення. В рамках наукової школи сформована та продовжує удосконалюватись базова теорія адресного впливу на нанорозмірні об'єкти органічних структур шляхом цільового енергетичного впливу.

За тематикою використання електромагнітного поля для сушіння рослинної сировини, було виконано ряд досліджень, результати яких опубліковано авторами в роботі [8]. Метою даного етапу дослідження $\epsilon$ вивчення кінетики процесів мікрохвильового сушіння рослинної сировини з різною внутрішньою структурою. Основною гіпотезою дослідження $\epsilon$ припущення, що мікрохвильовий спосіб енергопідведення може якнайкраще відповідати задачі вологовидалення з капілярно-пористих структур, якими в більшій частині і $\epsilon$ рослинна сировина. Особливості взаємодії мікрохвильового поля з вологою в матеріалі дозволяють розраховувати на високу інтенсивність вологовидалення з частинок (зерен) рослинної сировини з складною багатошаровою структурою. Детально особливості взаємодії електромагнітного поля з вологою, що розподілена в капілярно-пористих структурах та математичні моделі, що описують процеси такої взаємодії проаналізовано в роботі [9]. Базова теорія наукової школи проф.. О.Г. Бурдо відображає процес сушіння як динамічний баланс декількох послідовно паралельних процесів, і такий підхід добре пояснює результати експериментальних досліджень отримані при сушінні рослинної сировини з використанням електромагнітного енергопідведення.

Адресний вплив на вологу, що міститься в матеріалі дозволяє шляхом дозування потужності енергопідведення досить точно впливати на баланс складних процесів, що протікають всередині та на поверхні частинок вологого матеріалу. Якщо основний вплив конвективного енергопідведення здійснюється виключно через поверхню частинки, та має відповідний градієнт від поверхні до внутрішніх шарів, то при мікрохвильовому сушінні нагріваються вологі шари частинки, зосереджені в ії серцевині і відповідно градієнт темпе-

Наукові праці, Том 83, випуск 1 Scientific Works, Volume 83, Issue 1 
ратури співпадає з градієнтом вологості. Саме така фізика процесу визначає наявність інтенсивного масообмінного потоку між внутрішніми шарами частинок та зовнішніми і в фіналі визначає високу продуктивність мікрохвильового сушіння. Відповідно процес вологовидалення має дещо інший характер порівняно 3 конвективним сушінням (рис.1).

Перша відмінність полягає в тому, що при мікрохвильовому нагріванні внутрішніх шарів, вологовидалення починається 3 мінімальною затримкою, практично без часу на розігрівання частинки. При цьому випаровується в першу чергу поверхнева волога та волога в великих капілярах слабо зв'язана з матеріалом частинки. Далі, по мірі збільшення температури вологих шарів, потік вологи від внутрішніх шарів до поверхні інтенсивно зростає, має нелінійний характер і не переходить в тривалу фазу «досушування», характерну для конвективного сушіння. Причиною високої швидкості вологовидалення, гіпотетично, $\epsilon$ те, що волога інтенсивно переміщається з глибоких шарів та все дрібніших капілярів, де із зменшенням ії кількості в матеріалі, все інтенсивніше зростає градієнт тиску.

Сам процес перерозподілу вологи в частинці маловивчений і потребує вияснення деталей. Особливо цікавим в ньому є специфічний режим при якому пухирці пару, що виникають розрізнено в об'ємі капілярів матеріалу, розширюючись, інтенсивно витісняють з капілярів рідину, що не встигла перейти в стан пару, (рис.2.). Виконуючи роль своєрідних «поршнів» парові кульки виконують корисну роботу транспортуючи на поверхню частинки як рідину так і нерозчинні в ній частинки. Такий режим, досліджений і описаний науковцями кафедри названо «механодифузією», особливості режиму детально викладено в роботі [8].

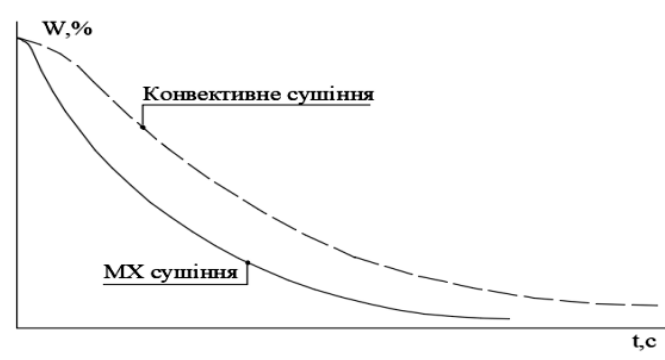

Рис. 1. Лінії конвективного та МХ сушіння

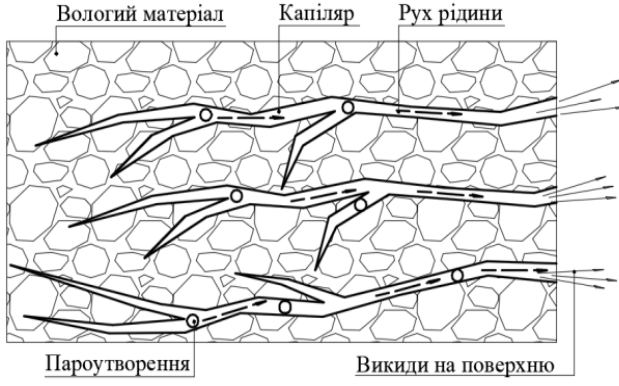

Рис. 2. Схематична модель бародифузії

Важливим наслідком даного відкриття є наукове обгрунтування можливості побудови сушильних апаратів з феноменально низькими енерговитратами, меншими ніж теоретичний мінімум в 2,4 МДж на кг випареної вологи. Кількість витраченої на сушіння енергії буде визначатись в першу чергу інтенсивністю досягнутого рівня бародифузії, так як саме при інтенсивному винесенні з капілярів матеріалу рідини, що ще не перейшла в стан пари, сушильна установка може показати надвисоку енергоефективність.

Зважаючи на складність внутрішніх процесів, що виникають в капілярно-пористих тілах у процесі їх висушування, змоделювати обставини та комплекс процесів, що ініціюють та підтримують явище бародифузії, аналітичним способом занадто складно. Саме тому, основним напрямом досліджень процесів мікрохвильового сушіння та режиму механодифузії зокрема, обрано експериментальне моделювання цільового процесу - взаємодії мікрохвильового поля та вологого матеріалу.

Для продуктів з відносно невисокою вологістю (зернові, бобові, порошки та більшість інших матеріалів на етапі досушування) мікрохвильовий, адресний енергопідведення може мати величезні переваги в швидкості, продуктивності та енергоефективності. Для термолабільних матеріалів ключовою буде можливість зміщення балансу процесу сушіння в бік слабоінтенсивного нагрівання і дотримання режимів низькотемпературного сушіння, із збереженням в сировині максимальної кількості цінних речовин.

Поєднання мікрохвильового сушіння з інфрачервоним дозволить значно інтенсифікувати процес вологовидалення $з$ поверхні частинок. Внаслідок особливостей мікрохвильового впливу на вологі внутрішні шари частинок рослинного матеріалу останні швидко розігріваються, виникають співнаправлені градієнти температури, тиску, вологості, що приводить до появи інтенсивного потоку вологи до поверхні частинок. При використанні інфрачервоного випромінювання одночасно, або відразу після мікрохвильового впливу, буде значно посилено відведення вологи з поверхні частинок що приведе до кращого розподілу градієнту вологості і посиленого вологовидалення.

Загальнопризнані та науково обгрунтовані технічні рішення для конструювання сушильних апаратів, що використовують в якості засобу енергопідведення електромагнітне поле надвисокої частоти відсутні.

В ході науково дослідних робіт кафедри створено дослідну мікрохвильову сушильну установку для сушіння сировини в тонкому шарі. Установка включає в себе стрічковий конвеєр, що проходить в металевому тунелі, який з'єднує в єдиний конструктив три прямокутні резонаторні камери генераторів мікрохвильового електромагнітного поля (магнетронів) електричною потужністю 800 Вт та три модулі інфрачервоного випромінювання. 


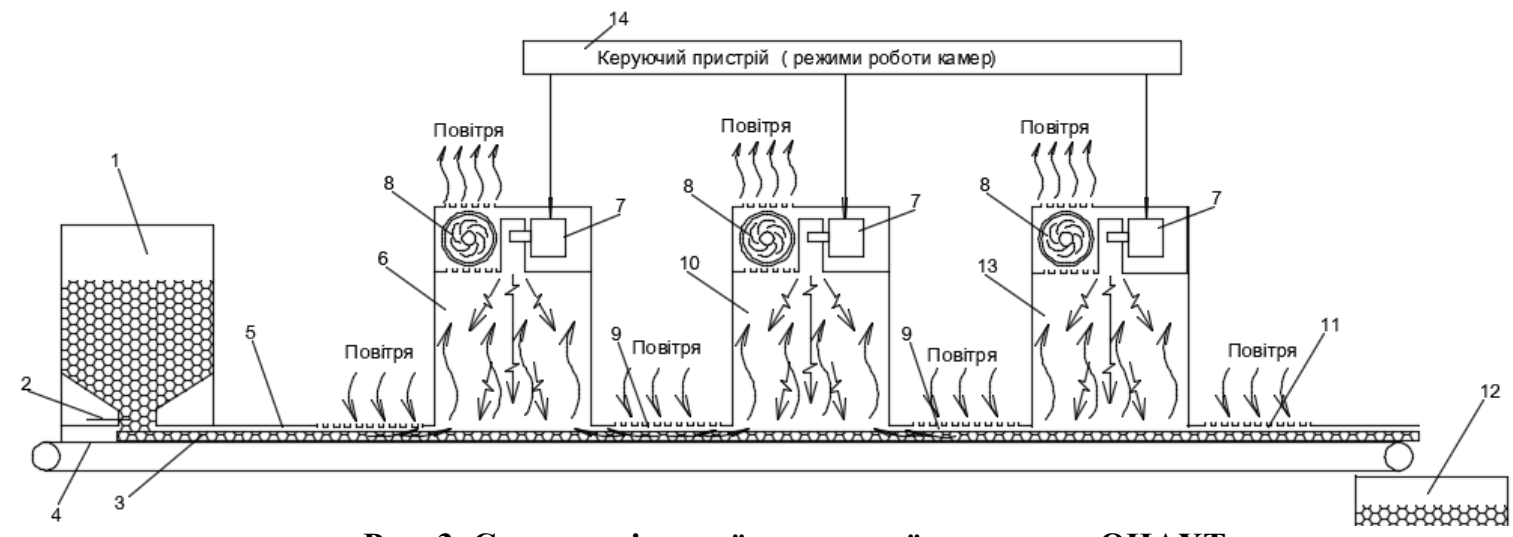

Рис. 3. Схема стрічкової сушильної установки ОНАХT

Характеристики установки:

- частота випромінювання МХ генераторів: $2450 \pm 50 \mathrm{MHz}$;

- електрична потужність МХ випромінювачів: $\leq 2,4$ кВт (регулюється);

- електрична потужність ІЧ випромінювачів: $\leq 5,4$ кВт (регулюється);

- швидкість конвеєра установки: 0-0,3 м / хв (регулюється);

- продуктивність по продукту, усереднено: 3-10 кг/год;

- габаритні розміри установки (д/ш/в): 3000х600x1200 мм.

Установка складається з бункера для вологого матеріалу 1, 3 дозуючим пристроєм 2, стрічкового конвеєра 4, для транспортування шару матеріалу 3 через зони сушки, вхідного 5 і вихідного 11 шлюзових тунелів. Основою установки є камери мікрохвильової обробки матеріалу 6, 10 і 13, кожна з яких обладнана магнетроном (генератором мікрохвильового випромінювання) 7 і вентилятором 8. Камери з'єднані між собою шлюзовими тунелями 9. Також сушарка має бункер для обробленого матеріалу 12 і систему управління потужністю магнетронів сушильних камер 14.

Результати експериментальних досліджень сушіння рослинних матеріалів. Експериментальна частина досліджень включала комплекс тестових сушінь рослинної сировини та напівфабрикатів у вигляді попередньо оброблених (підготовлених та нарізаних) плодів і овочів. Результати тестових сушінь показали, що висушені продукти мають значно краще збережені кольорову палітру, смак та текстуру порівняно 3 продуктами традиційного сушіння.

Визначення кінетики процесу мікрохвильового сушіння проводилось з використанням спеціально відібраних видів сировини. Значний науковий інтерес представляють процеси мікрохвильового сушіння складних за внутрішньою структурою матеріалів, з якими конвективне сушіння справляється недостатньо ефективно. Прикладом такого рослинного матеріалу може бути насіння соняшника.

Насіння соняшника має жорстку оболонку та ізольоване цією оболонкою зерно, вологе і цінне вмістом олії. При конвективному сушінні тепло передається спочатку оболонці а вже від неї зернині. Випарена внаслідок цього процесу волога має спочатку проникнути через вже висушену жорстку оболонку, і це не сприяє інтенсивному вологовидаленню. При мікрохвильовому енергопідведенні нагрівання буде проходити по всьому об'ємі насінини, при цьому більш волога зернина має нагріватись швидше і випарена волога має проникати через ще не висушену оболонку значно ефективніше завдяки формуванню в насінині однонаправлених градієнтів температури, тиску, та вологості. Що важливо, саме для соняшникового насіння - температура процесу, достатня для ефективного вологовидалення, має бути значно нижча ніж при конвективному сушінні, а це значно зменшує небезпеку перегрівання сировини та небезпеку ії пошкодження в процесі сушіння.

Для підтвердження справедливості таких висновків проведено серію дослідів з сушінням насіння соняшника. В ході процесу обробки безперервно контролювалась температура шару насіння та періодично вологість. Так як дослідна установка має лише три сушильних модулі, робота багатозонної мікрохвильової сушарки моделювалась послідовним пропуском невеликої партії зерна через сушарку декілька разів. В даному дослідженні проводилось вісім таких послідовних прогонів, що відповідає послідовній обробці потоку матеріалу в 24 камерній сушильній установці. В процесі переміщення насіння між прогонами вимірювалась вологість зерен та проводилось зважування партії насіння для визначення величини вологовидалення, в подальшому дані оброблялись і систематизувались. Було проведено дослідження впливу на процес вологовидалення потужності енергопідведення. Досліджено параметри процесу при потужності магнетронів еквівалентному енергопідведенню 45, 30 та 15 кВт/м². Результуючі залежності відображено на графіках, рис. 4. 


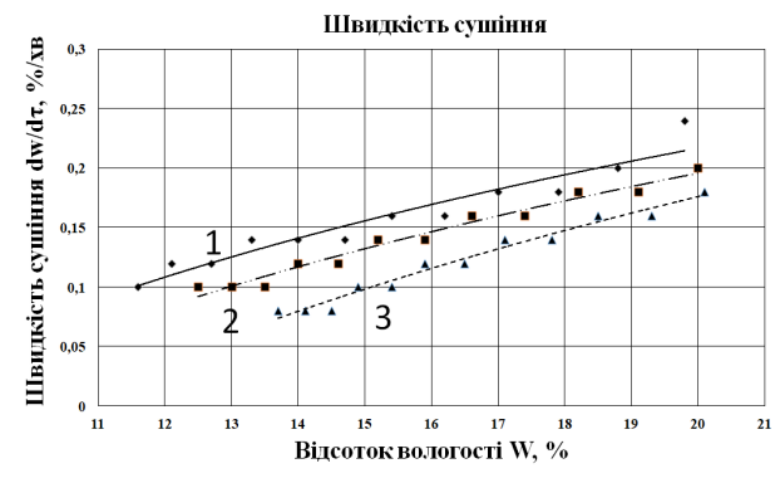

a)

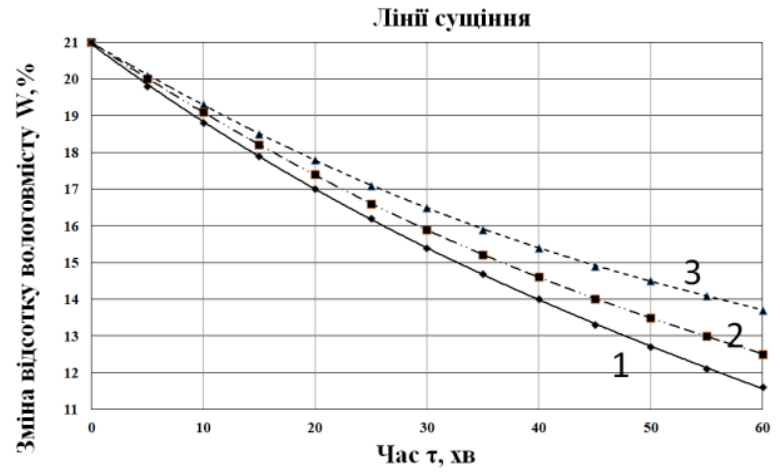

б)

Рис. 4 Графіки МХ сушіння тонкого рухомого шару насіння соняшника при різних потужностях поля. МХ потужність сушильних модулів: $145 \mathrm{\kappa BT} / \mathrm{m}^{2}, 230 \mathrm{\kappa BT} / \mathrm{M}^{2}, 315 \mathrm{\kappa BT} / \mathrm{m}^{2}$. Навантаження стрічки $\mathrm{m}=$ $3,96 \kappa г / \mathrm{M}^{2}$, швидкість стрічки $\mathrm{V}=0,025 \mathrm{M} / \mathrm{c}$.

а) залежність між швидкістю сушіння та вологістю шару; б) лінії сушіння.

Іншим важливим фактором, який визначає вплив на хід вологовидалення є тривалість обробки матеріалу електромагнітним полем. Для визначення даної залежності проведено серію експериментів при яких потужність мікрохвильового енергопідведення була фіксованою, 33 кВт/м², а швидкість стрічки конвеєра встановлювалась відповідно 0,0071, 0,0187 та 0,025 м/с. Інші параметри експерименту були аналогічними попередньому етапу. Результуючі залежності відображено на графіках, рис. 5.

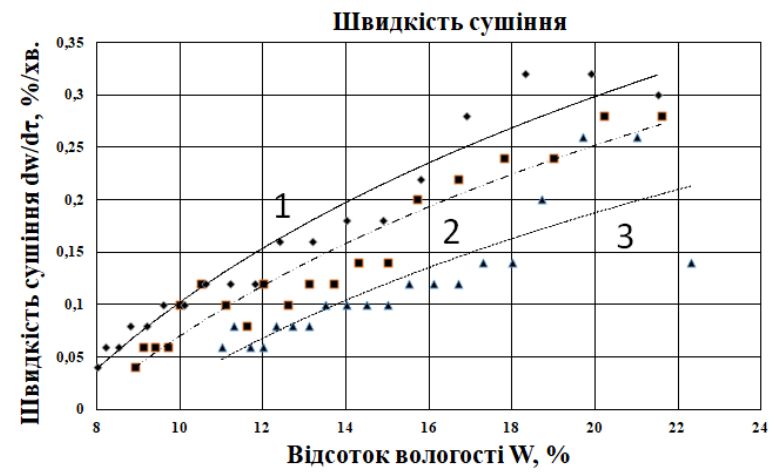

a)

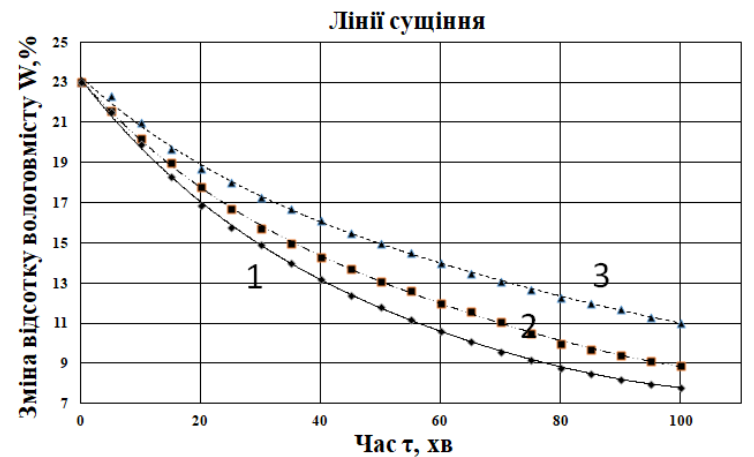

б)

Рис. 5 Графіки МХ сушіння тонкого рухомого шару насіння соняшника при різних швидкостях стрічки. Швидкість стрічки конвеєра:1- 0,0071 м/с, 2- 0,0187 м/с, 3- 0,025 м/с. Навантаження стрічки $\mathrm{m}=$ $3,96 \kappa г / \mathrm{M}^{2}$. Потужність магнетронів $\mathrm{N}=33 \mathrm{\kappa BT} / \mathrm{m}^{2}$.

а) залежність між швидкістю вологовидалення та вологістю; б) лінії сушіння.

В результаті обробки результатів встановлено, що зменшення вологості соняшника з 21 до 12 відсотків, при використанні мікрохвильового енергопідведення з питомою потужністю $45 \mathrm{kB} / \mathrm{m}^{2}$, проходить на протязі 55 хв. При такому режимі максимальна температура продукту не перевищувала $42{ }^{\circ} \mathrm{C}$. Швидкість вологовидалення на початку процесу складала понад 0,22 \%/хв. і поступово зменшувалась до 0,1%/хв. при досягненні цільової вологості в $12 \%$.

Аналогічно, при дослідженні впливу швидкості стрічки на процес МХ сушіння виявлено, що зменшення вологості соняшника $323 \%$ до $12 \%$, при використанні мікрохвильового енергопідведення 3 питомою потужністю 33 кВт/м², та при найменшій дослідженій швидкості 0,0071 м/с, сушіння проходить на протязі 50 хв. При такому режимі максимальна температура продукту майже досягала $60{ }^{\circ} \mathrm{C}$. Швидкість вологовидалення на початку процесу складала понад 0,32 \%/хв. і поступово зменшувалась до 0,15 \%/хв. при досягненні цільової вологості в $12 \%$.

Результати дослідження дозволяють стверджувати, що технології мікрохвильового сушіння цілком реально застосовувати для високопродуктивної та високоякісної переробки рослинної сировини.

Одним із найбільш перспективних варіантів подальшого удосконалення сушильних апаратів стрічкового типу є використання в них комбінованого енергопідведення. Серед варіантів комбінованих способів енергопідведення, найбільш доцільним, з точки зору енергоефективності процесу сушіння, можна розглядати комбінацію мікрохвильового та інфрачервоного (ІЧ) енергопідведення. Для визначення потенціальних мож- 
ливостей ІЧ енергопідведення для подальшого використання в установках стрічкового типу було проведено серію дослідів з нерухомим шаром матеріалу. В якості об'єкту сушіння було обрано рослинну сировину зі значною початковою вологістю - моркву, попередньо підготовлену, очищену та нарізану дисками.

Для дослідження використовувався дослідний стенд у вигляді сушильної камери з верхнім розташуванням інфрачервоного випромінювача, потужністю $1,88 \ldots 11,25 \mathrm{\kappa BT} / \mathrm{M}^{2}$ та платформою для розміщення шару матеріалу прикріпленої до підвісу цифрових вагів, з'єднаних через цифровий інтерфейс 3 програмою для реєстрації параметрів експерименту. В ході експерименту, вологий матеріал (морква, нарізана дисками товщиною 3 мм., загальною вагою зразка 50 гр.) щільно розкладалась на платформі і витримувалась в сушильній камері заданий час. Вага зразка фіксувалась безперервно, температура - через рівні проміжки часу.

Проведено серію дослідів з чотирма рівнями потужності інфрачервоного випромінювача: 1.88, 3.75 , 6.00, 8.75 та 11.25 кВт/м². Результуючі залежності представлено на рис. 6.

Лінії сушіння

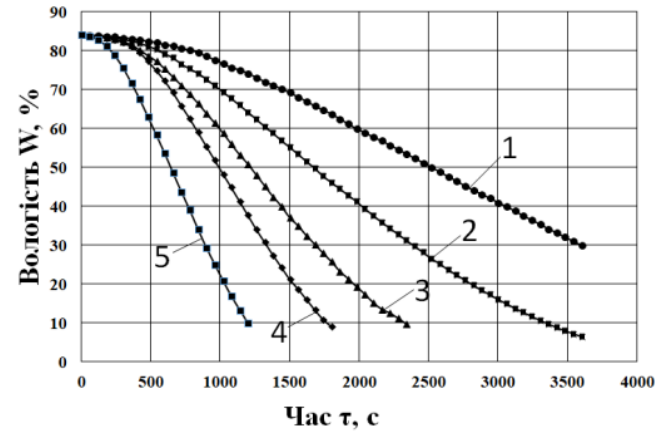

a)
Швидкість вологовидалення

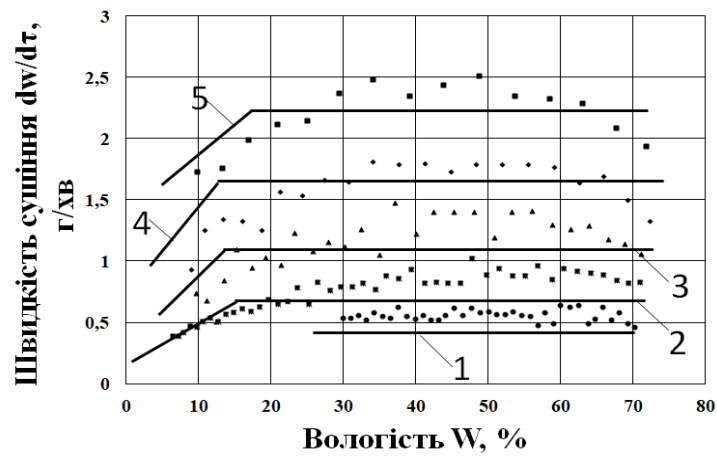

б)

Рис. 6. Графіки сушіння тонкого шару моркви при різних значеннях ІЧ енергопідведення.

Потужність ІЧ випромінювання: $1-1,88 \mathrm{\kappa BT} / \mathrm{m}^{2}, 2-3,75 \mathrm{\kappa BT} / \mathrm{m}^{2}, 3-6 \mathrm{\kappa BT} / \mathrm{m}^{2}, 4-8,75$ кВт/м $\mathrm{m}^{2}, 5-11,25$ кВт/м². Навантаження сушильної камери $\mathrm{m}=4,13 \mathrm{\kappa г} / \mathrm{m}^{2}$.

а) лінії сушіння; б) зміна швидкості вологовидалення в ході процесу сушіння.

Для визначення величини впливу товщини шару на кінетику процесу вологовидалення проведено ряд дослідів з сушінням шару моркви різної товщини. Як і в першій серії дослідів морква, нарізана дисками, щільним шаром викладалась на платформу. В кожному досліді товщина дисків вибиралась різною. Досліджено процеси сушіння для шару моркви величиною (товщиною дисків) 3, 5, 7 та 10 мм. Результуючі залежності представлено на рис. 7.

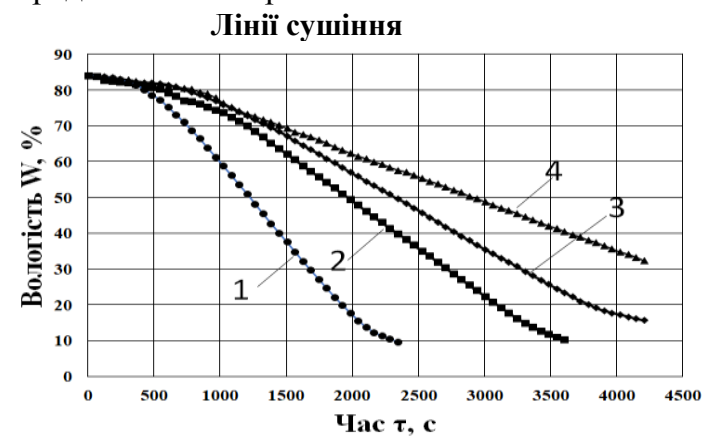

a)

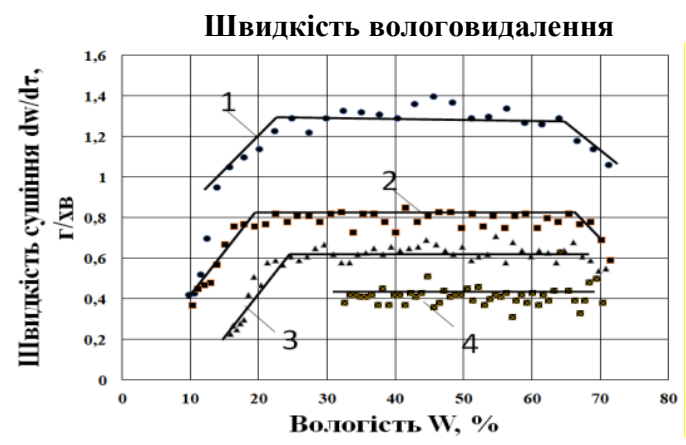

б)

Рис. 7. Графіки ІЧ сушіння шару моркви при різних значеннях товщини шару.

Потужність ІЧ випромінювання: 6 кВт/м². Товщина шару: $1-3$ мм, $2-5$ мм, $3-7$ мм, $4-10$ мм.

а) лінії сушіння; б) зміна швидкості вологовидалення в ході процесу сушіння.

Ще однією позитивною особливістю виявленою в ході дослідження процесу сушіння моркви інфрачервоним випромінюванням є те, що в процесі сушіння у висушеному матеріалі було повністю збережено вміст одного з найбільш цінних компонентів моркви, комплексу речовин - каротиноїдів.

Було досліджено вміст каротиноїдів у вихідному (вологому) матеріалі та у висушеному. Встановлено, що при нетривалому сушінні, з температурами, що перевищують температуру руйнування корисних речовин, цінні компоненти зберігаються повною мірою і процес їх руйнування не відбувається. Результати дослідження представлено на рис. 8. 


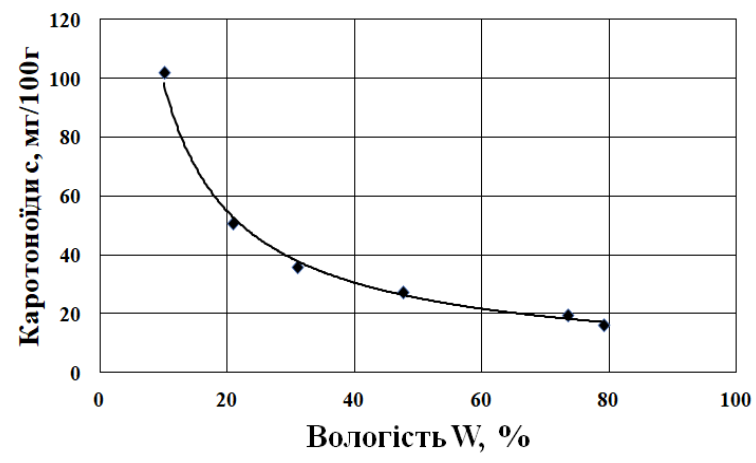

a)

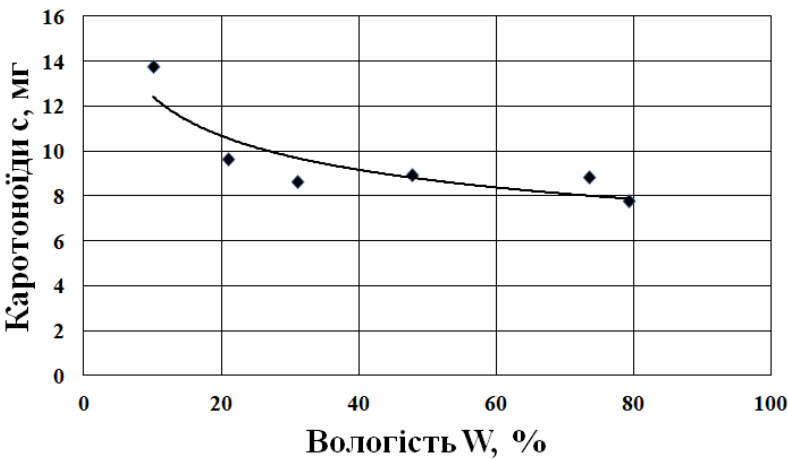

б)

Рис. 8 Графік зміни вмісту каротиноїдів в залежності від вологості моркви. Потужність ІЧ випромінювання: 6 кВт/м². Товщина шару: 3 мм. Завантаження: $4,13 \mathrm{\kappa r} / \mathrm{m}^{2}$. а) вміст каротиноїдів за даними лабораторних досліджень; б) фактична зміна вмісту каротиноїдів в процесі сушіння.

Каротиноїди руйнуються при температурі $70{ }^{\circ} \mathrm{C}$, проте, в ході експерименту температура деякий час перевищувала цей показник. Після обробки продукту протягом 20 хвилин при температурі, яка змінювалась в межах $70-100{ }^{\circ} \mathrm{C}$, встановлено, що вміст каротиноїдів не зменшився.

Висновок.

Відповідно до мети і тематики наукової роботи проведено експериментальне дослідження процесу вологовидалення з рухомого шару рослинної сировини під впливом мікрохвильового випромінювання, та процесу вологовидалення 3 нерухомого шару під впливом інфрачервоного випромінювання. Дослідження проведено на дослідній стрічковій, мікрохвильовій сушильній установці та дослідницькому стенді з інфрачервоною сушильною камерою. В ході проведених випробувань досліджено кінетику процесів вологовидалення 3 насіння соняшника та різаної моркви, встановлено основні параметри та обмеження процесів мікрохвильового та інфрачервоного сушіння для обраних об'єктів.

\section{References}

1. Filonenko, G.K., Grishin, M.A., Gol'denberg, Y.M. (1971). Sushka pishchevykh rastitel'nykh materialov: uchebnoye posobiye. - M.: Pishchevaya promyshlennost, 435.

2. Burich, O., Berki, F. (1978). Sushka plodov i ovoshchey: per. s veng. Spravochnoye posobiye. -M.: Pishchevaya promyshlennost, 280.

3. Shivhare, U. \& Raghavan, Vijaya \& Bosisio, R. \& Giroux, M. (1993). Microwave Drying of Soybean at 2.45 GHz. The Journal of microwave power and electromagnetic energy: a publication of the International Microwave Power Institute. 28. 11-17. 10.1080/08327823.1993.11688200.

4. Burdo, O., Povarova, N., \& Melnyk, L. (2019). Kinetyka ta enerhetyka znevodnennya m'yasa ptytsi v umovakh vakuumu ta mikrokhvyl'ovoho polya. Food Science and Technology, 12(4). https://doi.org/10.15673/fst.v12i4.1218

5. Burdo, O.G. (2019). Tekhnologii napravlennogo energeticheskogo deystviya v APK: Naukoví pratsí ONAKHT. Odesa, ONAKHT, T. 1, vip. 41., $42-46$.

6. Snezhkin, YU.F., Buryak, L.A., Khavin, A.A. (2004). Energosberegayushchiye teplotekhnologii proizvodstva pishchevykh poroshkov iz vtorichnykh syr'yevykh resursov: monografiya. Kiyev, NAN Ukrainy, izd. «Naukova dumka», 227.

7. Burdo, O.G. (2010). Evolyutsiya sushil'nykh ustanovok. Odessa: Poligraf, 368.

8. Bandura, V. M., Marenchenko, O.I., Pilipenko, E.O., Katasonov, O.V. (2017). Kinetika sushinnya oliynoi sirovini v elektromagnitnomu poli: Naukovi pratsi ONAKHT. Odesa, ONAKHT. T. 81, vipusk 1, 94-99.

9. Burdo, O.G., Terziyev, S.G., Bandura, V.N., Yarovoy, I.I. (2016). Mekhanodiffuzionnyy effekt - novoye yavleniye v teplomassoperenose: MMF. Minsk, Belorus'. 224-228.

Отримано в редакцію 07.04.2019

Прийнято до друку 16.06.2019
Received 07.04.2019

Approved 16.06.2019 